\title{
Genetic parameters for dry matter intake in primiparous Holstein, Nordic Red, and Jersey cows in the first half of lactation
}

\author{
B. Li, ${ }^{*}{ }^{1}$ W. F. Fikse, ${ }^{*}$ J. Lassen, $†$ M. H. Lidauer, $\ddagger$ P. Løvendahl, $†$ P. Mäntysaari, $\ddagger$ and B. Berglund ${ }^{*}$ \\ *Department of Animal Breeding and Genetics, Swedish University of Agricultural Sciences, SE-750 07 Uppsala, Sweden \\ †Department of Molecular Biology and Genetics, Aarhus University, DK-8830 Tjele, Denmark \\ ‡Natural Resources Institute Finland, Green Technology, Fl-31600 Jokioinen, Finland
}

\begin{abstract}
Dry matter intake (DMI) is a key component of feed efficiency in dairy cattle. In this study, we estimated genetic parameters of DMI over the first 24 lactation weeks in 3 dairy cattle breeds: Holstein, Nordic Red, and Jersey. In total, 1,656 primiparous cows (717 Holstein, 663 Nordic Red, and 276 Jersey) from Denmark, Finland, and Sweden were studied. For each breed, variance components, heritability, and repeatability for weekly DMI were estimated in 6 consecutive periods of the first 24 lactation weeks based on a repeatability animal model. Genetic correlations for DMI between different lactation periods were estimated using bivariate models. Based on our results, Holstein and Nordic Red cows had similar DMI at the beginning of lactation, but later in lactation Holstein cows had a slightly higher DMI than Nordic Red cows. In comparison, Jersey cows had a significantly lower DMI than the other 2 breeds within the first 24 lactation weeks. Heritability estimates for DMI ranged from 0.20 to 0.40 in Holsteins, 0.25 to 0.41 in Nordic Red, and 0.17 to 0.42 in Jerseys within the first 24 lactation weeks. Genetic and phenotypic variances for DMI varied along lactation within each breed and tended to be higher in the middle of lactation than at the beginning of the lactation. High genetic correlations were noted for DMI in lactation wk 5 to 24 in all 3 breeds, whereas DMI at early lactation (lactation wk 1 to 4 ) tended to be genetically different from DMI in the middle of lactation. The 3 breeds in this study might differ in their genetic variances for DMI, but the differences were not statistically significant in most of the studied periods. Breed differences for the genetic variance tended to be more obvious than for heritability. The potential breed differences in genetic variation for DMI should be considered in a future study using feed intake information from multiple breeds.
\end{abstract}

Received November 10, 2015.

Accepted May 13, 2016.

${ }^{1}$ Corresponding author: bingjie.li@slu.se
Key words: feed efficiency, dry matter intake, dairy cattle, heritability, genetic correlation

\section{INTRODUCTION}

Feed accounts for the largest part of operating costs in dairy production (European Commission, 2013; USDA, 2016), and feed intake is the key component of all available measures of feed efficiency. Currently, measurement of feed intake for individual cows is available only in research or nucleus herds. Insufficient recording of feed intake, in large part due to high cost, has hindered accurate estimation of genetic parameters as well as accurate selection of feed-efficient dairy cattle. Genetic studies on feed intake in dairy cattle call for larger data sets using information from multiple data sources (e.g., multiple countries or breeds).

Genetic variation for feed intake in the Holstein breed has been widely studied (e.g., Korver, 1988; Berry et al., 2014; Manzanilla Pech et al., 2016). In Holsteins, heritability estimates for DMI were estimated to range from 0.04 to 0.54 (e.g., Veerkamp and Thompson, 1999; Buttchereit et al., 2011; Berry et al., 2014). Heritability was found to vary along lactation, although the trajectory of heritability along lactation is still controversial (e.g., Karacaören et al., 2006; Manzanilla Pech et al., 2014a; Tetens et al., 2014). Large standard errors in most of the previous studies make it difficult to compare and differentiate the heritability estimates to clarify the trajectory. In addition, a low genetic correlation was reported for DMI between early lactation and the rest of lactation in Holstein (e.g., Hüttmann et al., 2009; Manzanilla Pech et al., 2014a; Tetens et al., 2014).

Apart from Holsteins, genetic studies on DMI in other dairy cattle breeds are rare and based on very small data sets (Søndergaard et al., 2002; Liinamo et al., 2012). Nordic Red was studied by Liinamo et al. (2012) using 291 primiparous cows, in which the heritability for DMI was estimated to range from 0.18 to 0.33 within lactation wk 2 to 30 , with large standard errors of estimates. They reported low but positive genetic correlations for DMI between lactation wk 2 and 
the middle of lactation. In addition, Søndergaard et al. (2002) reported the heritability for daily energy intake to be 0.14 based on a combined population of 293 lactating Jersey, Nordic Red, and Holstein cows in total.

The main limitations of previous studies on DMI in dairy cows are the uncertainty of estimates due to large standard errors and the domination by studies on the Holstein breed (e.g., Berry et al., 2014; Manzanilla Pech et al., 2014a). Larger data sets are necessary for accurate estimation of genetic parameters for DMI, and gaps remain in estimates of the genetic parameters for DMI in other dairy cattle breeds (e.g., Jersey, Nordic Red). One solution could be to join DMI data from multiple countries or breeds. Some international collaborative studies have been completed using feed intake in Holsteins, which made it possible to develop genetic and genomic evaluations of feed intake in Holstein through joining multiple-country data (Berry et al., 2014; de Haas et al., 2015; Manzanilla Pech et al., 2016). Feed intake information from multiple breeds, however, has not been used in previous studies. To assess the possibility of future genetic evaluation using DMI data from multiple breeds, information on the genetic variation and genetic parameters for DMI in the particular dairy cattle breeds is needed.

The objective of our study was to estimate the genetic parameters for DMI in primiparous Holstein, Nordic Red, and Jersey in different lactation periods within the first 24 lactation weeks. Heritability estimates and genetic variances for DMI as well as the genetic correlations for DMI between different lactation periods were compared within and between breeds along lactation.

\section{MATERIALS AND METHODS}

\section{Animals, Feeding, and Data Recording}

A total of 2,109 cows from 3 dairy breeds (905 Holstein, 872 Nordic Red, and 332 Jersey) were included in the original data set. The cows were from the Danish Cattle Research Center (http://www.KFC-Foulum. dk), Natural Resources Institute Finland Rehtijärvi research herd (Jokioinen, Finland) and Minkiö research herd (Jokioinen, Finland), and Swedish University of Agricultural Sciences Kungsängen research herd (Uppsala, Sweden) and Öjebyn research herd (Öjebyn, Sweden). The 291 Nordic Red cows studied by Liinamo et al. (2012) were from the Rehtijärvi research herd (Jokioinen, Finland) and were part of our data set. The cows calved between 1991 and 2014 for Holstein, between 1994 and 2013 for Nordic Red, and between 2002 and 2014 for Jersey. The cows were involved in several trials where feeding conditions were slightly different between trials (Åkerlind et al., 1999; Mäntysaari et al.,
2003, 2004, 2005, 2012; Patel, 2012; Berry et al., 2014; Mäntysaari and Mäntysaari, 2015). In most of the trials included in our study the cows were fed a TMR plus a fixed amount of concentrate, but there were also trials in which cows were fed forage and concentrate separately to fulfill specific feeding conditions. The feed offered to cows was measured individually and feed refusals were recorded to calculate the feed intake of individual cows. The DM contents in TMR, concentrates, and forages were analyzed regularly and the compositions were aligned and merged with feed intake records to obtain daily DMI values for individual cows.

\section{Data Editing}

The original data set consisted of 111,129 records of weekly DMI from 2,109 cows of the 3 breeds, where a weekly DMI was the average of 7 daily DMI measurements from a particular lactation week of an individual cow. The cows were from parity 1 to 8 . In our study, only DMI records of the primiparious cows within the first 24 lactation weeks were included, resulting in a total of 33,311 weekly DMI records from 1,751 primiparous cows (771 Holstein, 696 Nordic Red, and 284 Jersey). Cows with less than 5 DMI records within the first $24 \mathrm{wk}$ were removed from the data set. Cows with ages at first calving of more than 36 mo were also removed from the data set, resulting in a data set with the cows' calving ages ranging from 22 to 36 mo. For each breed, those trials with less than 10 records per trial were removed from the data set.

After editing, the final data set of our study consisted of 32,929 weekly DMI records from 1,656 primiparous cows (717 Holstein, 663 Nordic Red, and 276 Jersey). Among all the studied cows, the Holstein cows were from Denmark (572 cows) and Sweden (145 cows); the Nordic Red cows were from Denmark (138 cows), Finland (446 cows), and Sweden (79 cows); the Jersey cows were from Denmark only.

The pedigree information was extracted from the Nordic Cattle Genetic Evaluation Database (NAV, Skejby, Denmark) by tracing back as many generations as possible for cows with DMI records. The number of animals within each pedigree was 9,612, 12,762, and 2,810 for Holstein, Nordic Red, and Jersey, respectively.

\section{Statistical Analysis}

The weekly DMI in the first 24 lactation weeks were grouped into 6 consecutive lactation periods of $4 \mathrm{wk}$ in length (Table 1). The number of animals with DMI observations differed across periods due to missing observations of some cows in some periods (Table 1). Generally, the number of DMI records increased from 
Table 1. Description of the number of cows and the number of records in 6 consecutive lactation periods of 4 wk within the first 24 lactation weeks in primiparous Holstein (HOL), Nordic Red (RDC), and Jersey (JER) cows

\begin{tabular}{lcccccccc}
\hline & & \multicolumn{3}{c}{ Number of cows } & & \multicolumn{3}{c}{ Number of records } \\
\cline { 3 - 5 } \cline { 7 - 9 } Period & $\begin{array}{c}\text { Lactation } \\
\text { week }\end{array}$ & HOL & RDC & JER & & HOL & RDC & JER \\
\hline 1 & $1-4$ & 670 & 583 & 274 & & 2,569 & 1,965 & 1,046 \\
2 & $5-8$ & 687 & 602 & 275 & & 2,655 & 2,287 & 1,057 \\
3 & $9-12$ & 670 & 586 & 262 & & 2,572 & 2,199 & 1,013 \\
4 & $13-16$ & 636 & 523 & 254 & & 2,431 & 1,987 & 986 \\
5 & $17-20$ & 617 & 501 & 241 & & 2,364 & 1,891 & 935 \\
6 & $21-24$ & 593 & 486 & 230 & & 2,286 & 1,788 & 898 \\
\hline
\end{tabular}

period 1 to 2 , mainly because DMI recording in the first lactation week was not available in some of the recording schemes.

The weekly DMI from different periods were considered as different traits. Within a period, the weekly DMI observations were considered as repeated measures of DMI for individual animals. In each breed, variance components for DMI of a particular lactation period were estimated using the following repeatability animal model:

$$
\begin{gathered}
\mathrm{y}_{\text {jmnpsq }}=\mu+\operatorname{Herd}_{\mathrm{j}}+\mathrm{b} \times \text { CalvAge }+ \text { Trial }_{\mathrm{m}} \\
+ \text { YS__Rec }_{\mathrm{n}}+\text { LacWk }_{\mathrm{p}}+\text { Trial }_{\mathrm{m}} \times \text { YS_Rec }_{\mathrm{n}} \\
+\mathrm{a}_{\mathrm{s}}+\mathrm{p}_{\mathrm{s}}+\mathrm{e}_{\mathrm{jmnpsq}},
\end{gathered}
$$

where $\mathrm{y}_{\mathrm{jmn} p s q}$ is the weekly DMI observation within a period, where a period included up to 4 DMI observations for each individual cow; $\mu$ is the overall intercept; Herd $_{j}$ is the fixed effect of herd, where Holstein cows were from 2 herds, Jersey cows were from 1 herd, and Nordic Red cows were from 4 herds; b is the regression coefficient of a linear regression on the covariable CalvAge for calving age, where the calving age ranged from 664 to $1,065 \mathrm{~d}$ in Holstein, from 658 to $992 \mathrm{~d}$ in Jersey, and from 674 to 1,094 d in Nordic Red; Trial ${ }_{\mathrm{m}}$ is the fixed effect of the trial where the data originated from, to adjust for the feeding difference between trials where Holstein were in 25 trials, Jersey were in 15 trials, and Nordic Red were in 16 trials; YS_Rec ${ }_{n}$ is the fixed effect of year-season of recording, where 4 seasons were defined (March to May, June to August, September to November, and December to February), and the level of year-season of recording with less than 10 records was regrouped to the level of its nearest yearseason of recording based on its recording date $(\mathrm{n}=1$ to 70 in Holstein, 1 to 48 in Jersey, and 1 to 60 in Nordic Red); LacWk $\mathrm{p}_{\mathrm{p}}$ is the fixed effect of the lactation week within period ( $\mathrm{p}=1$ to 4 ); Trial $_{\mathrm{m}} \times \mathrm{YS}_{\mathrm{N}} \operatorname{Rec}_{\mathrm{n}}$ is the fixed effect of the interaction between trial and year-season of recording; $a_{\mathrm{s}}$ is the random additive ge- netic effect with $\operatorname{var}(\mathrm{a}) \sim \mathrm{N}\left(0, \mathbf{A} \sigma_{a}^{2}\right)$, where $\sigma_{a}^{2}$ is the additive genetic variance and $\mathbf{A}$ is the relationship matrix; $p_{\mathrm{s}}$ is the random permanent environmental effect with $\operatorname{var}(\mathrm{p}) \sim N\left(0, \mathbf{I} \sigma_{p}^{2}\right)$, where $\sigma_{p}^{2}$ is the permanent environmental variance and $\mathbf{I}$ is the identity matrix; $\mathrm{e}_{\mathrm{jmnpsq}}$ is the random residual with $\operatorname{var}(\mathrm{e}) \sim N\left(0, \mathbf{I} \sigma_{e}^{2}\right)$, where $\sigma_{e}^{2}$ is the residual variance.

The fixed effects included in the repeatability animal model were tested for significance for DMI $(P<$ 0.05 ) by PROC MIXED in SAS 9.3 (SAS Institute Inc., Cary, NC), using a mixed model including these fixed effects and a random animal effect without using pedigree relationship. Within each breed, the residuals of weekly DMI observations generated from this mixed model were tested following the normal distribution by PROC UNIVARIATE in SAS 9.3 (SAS Institute Inc.).

Variance components, heritability, and repeatability of DMI for each breed within each lactation period were estimated using the repeatability animal model by restricted maximum likelihood (REML) by ASReml 3.0 (Gilmour et al., 2009). Bivariate analyses were carried out to estimate genetic correlations for DMI between different lactation periods in each breed.

\section{RESULTS}

\section{Breed Characteristics in DMI}

The shape of the mean DMI profiles within the first $24 \mathrm{wk}$ of lactation was similar between breeds (Figure 1). The DMI of cows increased after calving until around lactation wk 12, and then it remained at a relatively stable level during lactation wk 12 to 24 . Holstein and Nordic Red cows had similar levels of DMI at the beginning of lactation, but later in lactation Holstein cows had a slightly higher DMI than Nordic Red cows (Figure 1; Table 2). In comparison, Jersey cows had a much lower DMI than Holstein and Nordic Red cows within the first 24 lactation weeks (Figure 1). Despite the differences in DMI, the 3 breeds had relatively con- 
Table 2. Descriptive statistics of average daily DMI $(\mathrm{kg} / \mathrm{d})$ with SD $(\mathrm{kg} / \mathrm{d})$, and the CV for DMI in 6 consecutive lactation periods of 4 wk length within the first 24 lactation weeks in primiparous Holstein (HOL), Nordic Red (RDC), and Jersey (JER) cows

\begin{tabular}{|c|c|c|c|c|c|c|c|c|c|}
\hline Period & \multicolumn{3}{|c|}{ Average daily DMI (kg/d) } & \multicolumn{3}{|c|}{$\mathrm{SD}(\mathrm{kg} / \mathrm{d})$} & \multicolumn{3}{|c|}{$\mathrm{CV}(\%)$} \\
\hline 2 & 18.29 & 17.95 & 14.89 & 2.52 & 2.67 & 2.07 & 14 & 15 & 14 \\
\hline 3 & 19.55 & 19.08 & 16.08 & 2.54 & 2.94 & 2.10 & 13 & 15 & 13 \\
\hline 4 & 19.85 & 19.42 & 16.61 & 2.61 & 2.97 & 2.06 & 13 & 15 & 12 \\
\hline 5 & 20.04 & 19.48 & 16.80 & 2.63 & 3.13 & 2.30 & 13 & 16 & 14 \\
\hline
\end{tabular}

sistent coefficients of variation $(\mathbf{C V})$ for DMI in each period (Table 2). For all 3 breeds CV for DMI in period 1 was around $20 \%$ and then decreased to around $15 \%$ in later lactation periods (Table 2).

In addition, the effect of year-season of recording significantly affected DMI in all 6 lactation periods in all 3 breeds. The effects of the age of first calving, lactation week, trial, and the interaction between trial and yearseason of recording significantly affected DMI in only some of the lactation periods.

\section{Heritability, Repeatability, and Variance Components}

For the first 24 lactation weeks, heritability estimates for DMI ranged from 0.20 to 0.40 in Holstein, 0.25 to 0.41 in Nordic Red, and 0.17 to 0.42 in Jersey (Table $3)$. The difference between breeds in the heritability for DMI was not significant due to large standard errors (Table 3). The repeatability was high in all periods for each breed, and the repeatability increased from around 0.68 in the first period of lactation to around 0.80 in later periods (Table 3 ).

Genetic and phenotypic variances for DMI varied along lactation (Table 4). The tendency of increased genetic variance from early to mid lactation was shown in Holstein and Jersey cows, whereas the tendency was not obvious in Nordic Red cows. Comparing the 3 breeds, Nordic Red and Jersey tended to have the highest and the lowest genetic variance for DMI, respectively. The potential breed difference was more obvious for genetic variances than for the heritability estimates. However, due to the large standard errors, the difference in genetic variances between breeds was not statistically significant in most of the periods, except for period 3 between Nordic Red and Jersey (Table 4). Phenotypic variances increased along the lactation in all 3 breeds. Nordic Red had significantly higher phenotypic variance than the other 2 breeds. Jersey had the lowest phenotypic variance among the 3 breeds, but Jersey also had the lowest mean DMI and a similar CV for DMI with Holstein and Nordic Red, which are larger-sized breeds (Table 2; Table 4).

\section{Genetic Correlations for DMI Between Lactation Periods}

Generally for all 3 breeds, DMI between adjacent periods were highly genetically correlated, and DMI for periods 2 to 6 were highly genetically correlated (Table 5). In Holstein, the genetic correlations for DMI between period 1 and mid-lactation periods (periods 3 to 6$)$ were significantly different from unity $(P<$ 0.05; Table 5). A significant difference was also found for DMI between periods 1 and 5 in Jersey. In Nordic Red, the differences for DMI between period 1 and later periods were not statistically significant, but DMI in period 1 tended to have weaker genetic correlations with periods 3 to 6 compared with the genetic correlations within periods 3 to 6 .

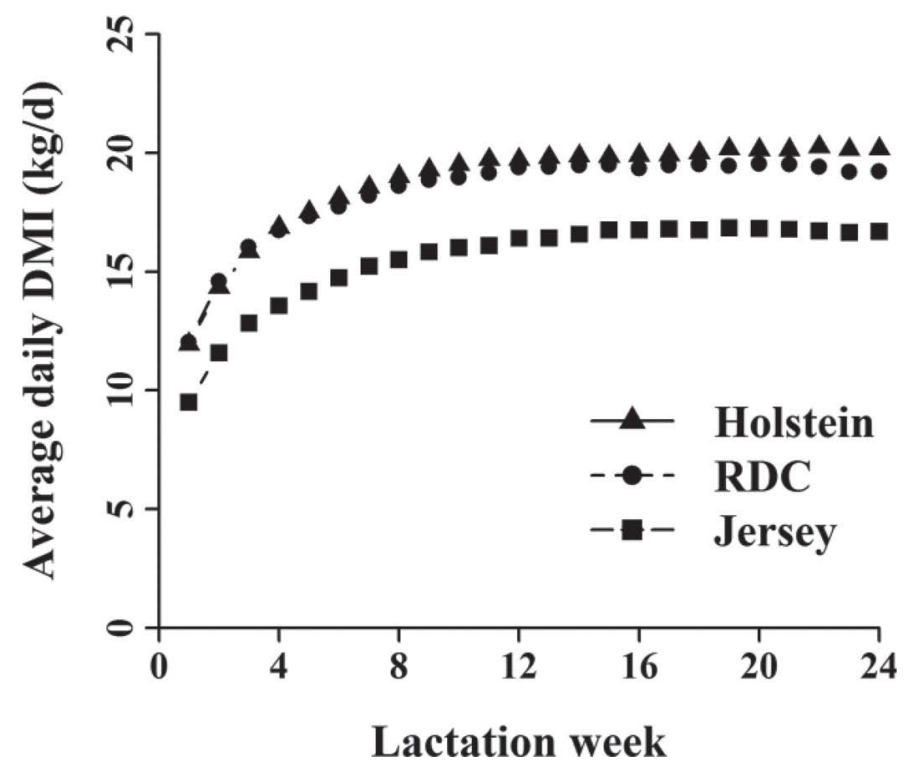

Figure 1. Average daily DMI $(\mathrm{kg} / \mathrm{d})$ within the first 24 lactation weeks in primiparous Holstein (HOL), Nordic Red (RDC), and Jersey (JER) cows. 
Table 3. Heritability (SE in subscript) and repeatability (SE in subscript) for DMI (kg/d) in 6 consecutive lactation periods of 4 wk within the first 24 lactation weeks in primiparous Holstein (HOL), Nordic Red (RDC), and Jersey (JER) cows

\begin{tabular}{|c|c|c|c|c|c|c|}
\hline \multirow[b]{2}{*}{ Period } & \multicolumn{3}{|c|}{ Heritability $^{1}$} & \multicolumn{3}{|c|}{ Repeatability $^{2}$} \\
\hline & $\mathrm{HOL}$ & $\mathrm{RDC}$ & JER & $\mathrm{HOL}$ & $\mathrm{RDC}$ & JER \\
\hline 1 & $0.26_{0.08}$ & $0.37_{0.10}$ & $0.29_{0.12}$ & $0.68_{0.02}$ & $0.68_{0.02}$ & $0.67_{0.03}$ \\
\hline 2 & 0.290 .08 & 0.260 .11 & $0.25_{0.12}$ & $0.74_{0.02}$ & 0.79 & $0.78_{0.02}$ \\
\hline 3 & $0.20_{0.08}$ & $0.41_{0.11}$ & $0.17_{0.11}$ & $0.78_{0.01}$ & $0.79_{0.01}$ & $0.75_{0.02}$ \\
\hline 4 & $0.25_{0.08}$ & $0.26_{0.11}^{0.11}$ & $0.31_{0.13}$ & $0.80_{0.01}$ & $0.81_{0.01}$ & $0.79_{0.02}^{0.02}$ \\
\hline 5 & $0.34_{0.09}$ & $0.25_{0.11}$ & $0.42_{0.14}$ & $0.78_{0.01}$ & $0.85_{0.01}$ & $0.79_{0.02}$ \\
\hline 6 & $0.40_{0.10}$ & $0.26_{0.12}$ & $0.29_{0.15}$ & $0.83_{0.01}$ & $0.83_{0.01}$ & $0.77_{0.02}$ \\
\hline
\end{tabular}

${ }^{1}$ All heritability estimates, except for one heritability estimate in period 3 in Jersey, deviate more than 1.645 $\times$ SE from $0(P<0.05)$.

${ }^{2}$ All repeatability estimates deviate more than $1.645 \times$ SE from $0(P<0.05)$.

Table 4. Genetic variance $\left(\sigma_{a}^{2}\right)$ and phenotypic variance $\left(\sigma_{p}^{2}\right.$; SE in subscript) for DMI $(\mathrm{kg} / \mathrm{d})$ in 6 consecutive lactation periods of $4 \mathrm{wk}$ within the first 24 lactation weeks in primiparous Holstein (HOL), Nordic Red (RDC), and Jersey (JER) cows

\begin{tabular}{|c|c|c|c|c|c|c|}
\hline \multirow[b]{2}{*}{ Period } & \multicolumn{3}{|c|}{ Genetic variance $^{1}$} & \multicolumn{3}{|c|}{ Phenotypic variance $^{2}$} \\
\hline & HOL & RDC & JER & HOL & RDC & JER \\
\hline 1 & $1.2_{0.4}$ & $1.9_{0.6}$ & $0.8_{0.3}$ & $4.4_{0.2}$ & $5.0_{0.3}$ & $2.6_{0.2}$ \\
\hline 2 & $1.3_{0.4}$ & $1.6_{0.7}$ & $0.8_{0.4}$ & $4.6_{0.2}$ & $6.0_{0.3}$ & $3.3_{0.3}$ \\
\hline 3 & $1.0_{0.4}$ & $3.0_{0.9}$ & $0.6_{0.4}$ & $5.1_{0.3}$ & $7.3_{0.4}$ & $3.4_{0.3}$ \\
\hline 4 & $1.3_{0.5}$ & $1.9_{0.8}$ & $1.1_{0.5}$ & $5.3_{0.3}$ & $7.3_{0.4}$ & $3.6_{0.3}$ \\
\hline 5 & $1.7_{0.5}$ & $1.9_{0.9}$ & $1.8_{0.7}$ & $5.0_{0.3}$ & $7.8_{0.5}$ & $4.4_{0.4}$ \\
\hline 6 & $2.1_{0.6}$ & $2.1_{1.0}$ & $1.5_{0.9}$ & $5.3_{0.3}$ & $8.0_{0.5}$ & $5.3_{0.5}^{0 . \pm}$ \\
\hline
\end{tabular}

${ }^{1}$ All estimates, except for one in period 3 in Jersey, deviate more than $1.645 \times$ SE from $0(P<0.05)$.

${ }^{2}$ All estimates deviate more than $1.645 \times$ SE from $0(P<0.05)$.

Table 5. Genetic correlations ${ }^{1}$ (above diagonal, SE in subscript) and phenotypic correlations (below diagonal, $\mathrm{SE}$ in subscript) for DMI $(\mathrm{kg} / \mathrm{d})$ between 6 consecutive lactation periods of 4 wk within the first 24 lactation weeks in primiparous Holstein (HOL), Nordic Red (RDC), and Jersey (JER) cows

\begin{tabular}{|c|c|c|c|c|c|c|c|}
\hline \multirow[b]{2}{*}{ Breed } & \multirow[b]{2}{*}{ Period } & \multicolumn{6}{|c|}{ Period } \\
\hline & & 1 & 2 & 3 & 4 & 5 & 6 \\
\hline $\mathrm{HOL}$ & $\begin{array}{l}1 \\
2 \\
3 \\
4 \\
5 \\
6\end{array}$ & $\begin{array}{cc}0.58^{0.02} & 0.46^{0.03} \\
0.35^{0.03} & 0.04 \\
0.31_{0} & 0.04 \\
0.28_{0} & 0.04\end{array}$ & $\begin{array}{l}1.00_{0.04} \\
0.68_{0.02} \\
0.57_{0.02} \\
0.51_{0.03}^{0.03} \\
0.47_{0.03}\end{array}$ & $\begin{array}{l}0.78^{*}{ }_{0.13} \\
0.98_{0.04} \\
0.72_{0.02} \\
0.64_{0.02} \\
0.57_{0.03}\end{array}$ & $\begin{array}{l}0.70^{2}{ }_{0.15} \\
0.89_{0.09} \\
0.99_{0.05} \\
0.73_{0.02} \\
0.68_{0.02}\end{array}$ & $\begin{array}{l}0.69^{*}{ }_{0.15} \\
0.88_{0.10} \\
0.98_{0.08} \\
0.98_{0.03} \\
0.73_{0.02}\end{array}$ & $\begin{array}{l}0.63^{*}{ }_{0.15} \\
0.85 \\
0.97 \\
0.09 \\
1.00 \\
0.99 \\
0.03\end{array}$ \\
\hline $\mathrm{RDC}$ & $\begin{array}{l}1 \\
2 \\
3 \\
4 \\
5 \\
6\end{array}$ & $\begin{array}{cc}0.57^{0.02} & 0.46^{0.03} \\
0.45 & 0.03 \\
0.42^{0.03} & 0.04 \\
0.36^{0}\end{array}$ & $\begin{array}{l}0.86_{0.11} \\
0.65_{0.02}^{0 .} \\
0.54_{0.03} \\
0.48_{0.03}^{0.04} \\
0.44_{0.04}\end{array}$ & $\begin{array}{l}0.96_{0.11} \\
0.99_{0.06} \\
0.66_{0.02} \\
0.60_{0.03} \\
0.55_{0.03}\end{array}$ & $\begin{array}{l}0.77_{0.17} \\
0.82_{0.16} \\
0.87_{0.09} \\
0.73_{0.02} \\
0.64_{0.02}\end{array}$ & $\begin{array}{l}0.90_{0.17} \\
0.91_{0.18} \\
0.84_{0.13} \\
0.98_{0.07} \\
0.73_{0.02}\end{array}$ & $\begin{array}{ll}0.78 & 0.22 \\
0.90 & 0.20 \\
0.93^{0.12} & \\
0.99 & 0.13 \\
0.95 & 0.10\end{array}$ \\
\hline JER & $\begin{array}{l}1 \\
2 \\
3 \\
4 \\
5 \\
6\end{array}$ & $\begin{array}{l}0.62_{0.03} \\
0.50_{0.04} \\
0.40_{0.05} \\
0.33_{0.06} \\
0.30_{0.06}\end{array}$ & $\begin{array}{l}0.85_{0.14} \\
0.66_{0.03} \\
0.52_{0.05} \\
0.44_{0.05}^{0} \\
0.32_{0.06}\end{array}$ & $\begin{array}{l}0.96_{0.16} \\
1.00_{0.11} \\
0.66_{0.03} \\
0.52_{0.05} \\
0.41_{0.05}\end{array}$ & $\begin{array}{l}0.98_{0.16}^{0.16} \\
0.93_{0.18} \\
0.98_{0.12} \\
0.69_{0.03} \\
0.57_{0.04}\end{array}$ & $\begin{array}{l}0.52^{*}{ }_{0.25} \\
0.97_{0.19} \\
0.99_{0.16} \\
1.00_{0.05} \\
0.71_{0.03}\end{array}$ & $\begin{array}{c}0.80_{0.30} \\
0.99_{0.21} \\
0.98_{0.24} \\
0.99_{0.11} \\
1.00_{0.05}\end{array}$ \\
\hline
\end{tabular}

${ }^{1}$ The genetic correlation estimates deviating more than $1.645 \times$ SE from $1(P<0.05)$ are marked with an asterisk $(*)$. 


\section{DISCUSSION}

\section{Heritability and Genetic Variances for DMI}

Heritability estimates for DMI in Holstein cows ranged from 0.20 to 0.40 in our study, which is consistent with the estimates of approximately 0.2 to 0.4 reported in previous studies in Holstein cows (Spurlock et al., 2012; Berry et al., 2014; Manzanilla Pech et al., 2016). The mid lactation periods had higher heritability estimates for DMI compared with the beginning of lactation for Holsteins. This was in agreement with recent studies showing a generally increased heritability for DMI from early to mid lactation in Holstein (Hüttmann et al., 2009; Spurlock et al., 2012; Manzanilla Pech et al., 2014a). However, other studies have also reported higher heritability at the beginning of lactation compared with later in lactation in Holstein (Buttchereit et al., 2011; Tetens et al., 2014).

We found that the heritability estimates for Nordic Reds (0.25-0.41) and for Jerseys (0.17-0.42) fell into the same range as that for Holsteins. It was difficult to compare the trajectory of heritability along lactation between breeds due to the standard errors of these estimates. In Nordic Red, Liinamo et al. (2012) estimated the heritability for DMI to be 0.18 to 0.33 within the first 30 lactation weeks, which was in agreement with our results considering the standard errors of estimates. This was expected because the data used by Liinamo et al. (2012) were part of the 663 Nordic Red cows in our study. In our study the data for Nordic Red were the most heterogeneous with respect to data sources, probably because data for Nordic Red were collected in 4 research farms in 3 countries with different recording schemes. In contrast, the Holstein cows in our study were from 2 research farms in 2 countries, and Jersey cows were only from 1 research farm in Denmark. For Holstein cows, whose data were mainly from one research farm with comprehensive data collection, heritability estimates were more consistent across periods. This demonstrated the importance of well-designed data collection to improve reliability of variance component estimates. This could also explain the higher phenotypic variances for DMI in Nordic Red than those in Holstein and Jersey in our study.

Genetic variances estimated for DMI in mid lactation were higher than at the beginning of lactation in Holstein and Jersey, and this tendency was not obvious in Nordic Red. Our result for Holsteins is in agreement with that of Veerkamp and Thompson (1999), who also showed relatively low genetic variances for DMI at the beginning of lactation and within the first 15 lactation weeks in Holstein. Results from our study indicate that the genetic variances for DMI might dif- fer between breeds, and the breed differences for the genetic variance tended to be more obvious than for heritability. Nordic Red cows tended to have higher genetic variances than the other 2 breeds. The higher genetic variances of Nordic Red might be due to the genetic heterogeneity of the Nordic Red cows, as they are a combination of 9 different breeds with large influences from Finnish Ayrshire, Swedish Red, and Red Danish cattle (Lidauer et al., 2015).

\section{Genetic Correlations for DMI Between Lactation Periods}

In Holsteins, the genetic correlations between period 1 and periods 3 to 6 were significantly different from unity, indicating a potentially different genetic basis for DMI between the start of lactation and mid lactation. A possible difference in genetic control of DMI was also found between period 1 and 5 in Jersey. Generally, genetic correlations for DMI tended to be lower between period 1 and mid lactation periods (periods 3 to 6 ) compared with the correlations within mid lactation periods (periods 3 to 6 ). This relatively weak genetic correlation between early and mid lactation was also shown in previous studies in Holstein and Nordic Red (e.g., Koenen and Veerkamp, 1998; Liinamo et al., 2012; Manzanilla Pech et al., 2014a). Several studies, including our own, found a low but positive genetic correlation between early and mid lactation (Hüttmann et al., 2009; Liinamo et al., 2012; Tetens et al., 2014), but studies in Holstein have also shown a negative genetic correlation between DMI in early and mid lactation (Karacaören et al., 2006; Buttchereit et al., 2011; Manzanilla Pech et al., 2014a). In general, cows increase feed intake and mobilize body reserves during early lactation to meet the energy demand for milk production (Van Arendonk et al., 1991; Collard et al., 2000; Mao et al., 2003). In mid lactation, body reserves are gradually restored and recovery in energy balance occurs (Mao et al., 2003). The nutritional requirements and metabolic changes from early to mid lactation influence feed intake of dairy cattle and might partly explain the low genetic correlation for feed intake between early and mid lactation.

Because DMI is currently difficult and expensive to measure, it is of interest to know if DMI in certain lactation periods could predict DMI in other periods so as to reduce the number of measurements needed across lactation. As early lactation is potentially genetically different from mid lactation for DMI, measurements of DMI in mid lactation could not be a strong predictor of DMI in early lactation and vice versa. Therefore, to predict DMI of an individual cow across lactation, it could be necessary to record DMI from separate time 
points in early, mid, and, perhaps, also in late lactation and consider all the information for the prediction. Our suggestion was in agreement with the previous study by Manzanilla Pech et al. (2014b), who calculated the accuracy of selection for DMI in the entire lactation using different recording schemes. Manzanilla Pech et al. (2014b) reported that when the number of DMI measurements was limited to 15 wk across lactation, spreading those measurements in different lactation periods gave high selection accuracy. In addition, our study suggests a highly genetically correlated period (lactation wk 9-24) as one potential period in which to measure DMI to be representative of mid lactation. If it is not practical to record data over a long period of time, period 5 to 6 (lactation wk 17-24) could be chosen owing to its high heritability and high genetic correlations with other mid lactation periods.

\section{Considerations on Utilizing DMI Data from Multiple Breeds}

Our results were based on data from research stations in different countries to achieve data sets of sufficient size to estimate genetic parameters for feed intake for each breed. One may speculate that this approach could be extended to combine data from different but reasonably similar breeds. However, our results also indicated that variance components for DMI could be different between breeds, although the breed differences were not significant in most of the lactation periods in our study. In that case, any possible breed difference needs to be accounted for properly. However, due to the limited data size of feed intake from research herds, especially for non-Holstein breeds, the potential breed differences or the size of the difference should be further studied by a larger data set of feed intake from multiple breeds. Another problem in using feed intake data from multiple breeds could be that breeds are not well connected (Lund et al., 2014), and in our study the 3 breeds have very few shared ancestors (data not shown).

\section{CONCLUSIONS}

We found moderate heritability (mainly from 0.2 to 0.4) for DMI within the first 24 lactation weeks in primiparous Holstein, Nordic Red, and Jersey cows. The genetic variance for DMI might differ between breeds, but the difference was not significant in most of the periods studied due to large standard errors. Breed differences for genetic variances tended to be more obvious than for heritability. Genetic and phenotypic variances for DMI varied along lactation and tended to be higher in mid lactation than at the beginning of lactation.
Genetic correlations for DMI were high in lactation wk 5 to 24, whereas DMI in the first lactation period (lactation wk 1 to 4 ) tended to be genetically different from DMI in subsequent lactation periods. The potential breed difference in genetic variation for DMI should be considered when using feed intake information from multiple breeds.

\section{ACKNOWLEDGMENTS}

This study was part of the joint project "Feed Utilization in Nordic Cattle (FUNC)" among Nordic countries (Denmark, Finland, Norway, and Sweden). The authors acknowledge the Danish Cattle Research Center (Foulum, Denmark), Natural Resources Institute Finland (Jokioinen, Finland), and the Swedish University of Agricultural Sciences (Uppsala, Sweden) for joining data. The authors also acknowledge the Swedish Farmers' Foundation for Agricultural Research (Stockholm, Sweden) for its financial support. The first author is enrolled in the Erasmus Mundus European Graduate School in Animal Breeding and Genetics (EGS-ABG; http://www.egsabg.eu/).

\section{REFERENCES}

Åkerlind, M., K. Holtenius, J. Bertilsson, and M. Emanuelson. 1999. Milk composition and feed intake in dairy cows selected for high or low milk fat percentage. Livest. Prod. Sci. 59:1-11.

Berry, D. P., M. P. Coffey, J. E. Pryce, Y. de Haas, P. Løvendahl, N. Krattenmacher, J. J. Crowley, Z. Wang, D. Spurlock, K. Weigel, K. Macdonald, and R. F. Veerkamp. 2014. International genetic evaluations for feed intake in dairy cattle through the collation of data from multiple sources. J. Dairy Sci. 97:3894-3905.

Buttchereit, N., E. Stamer, W. Junge, and G. Thaller. 2011. Short communication: Genetic relationships among daily energy balance, feed intake, body condition score, and fat to protein ratio of milk in dairy cows. J. Dairy Sci. 94:1586-1591.

Collard, B. L., P. J. Boettcher, J. C. M. Dekkers, D. Petitclerc, and L. R. Schaeffer. 2000. Relationships between energy balance and health traits of dairy cattle in early lactation. J. Dairy Sci. $83: 2683-2690$

de Haas, Y., J. E. Pryce, M. P. L. Calus, E. Wall, D. P. Berry, P. Løvendahl, N. Krattenmacher, F. Miglior, K. Weigel, D. Spurlock, K. A. Macdonald, B. Hulsegge, and R. F. Veerkamp. 2015. Genomic prediction of dry matter intake in dairy cattle from an international data set consisting of research herds in Europe, North America, and Australasia. J. Dairy Sci. 98:6522-6534.

European Commission. 2013. Analysis of milk margins. Pages 8-26 in EU Dairy Farms Report 2013. European Commission on Agricultural and Rural Development. Accessed Jun. 16, 2016. http://ec.europa.eu/agriculture/rica/pdf/Dairy_Farms_ report_2013_WEB.pdf.

Gilmour, A. R., B. J. Gogel, B. R. Cullis, and R. Thompson. 2009. ASREML User's Guide Release 3.0. VSN International Ltd., Hemel Hempstead, U.K.

Hüttmann, H., E. Stamer, W. Junge, G. Thaller, and E. Kalm. 2009 Analysis of feed intake and energy balance of high-yielding first lactating Holstein cows with fixed and random regression models. Animal 3:181-188.

Karacaören, B., F. Jaffrézic, and H. N. Kadarmideen. 2006. Genetic parameters for functional traits in dairy cattle from daily random regression models. J. Dairy Sci. 89:791-798. 
Koenen, E. P. C., and R. F. Veerkamp. 1998. Genetic covariance functions for live weight, condition score, and dry-matter intake measured at different lactation stages of Holstein Friesian heifers. Livest. Prod. Sci. 57:67-77.

Korver, S. 1988. Genetic aspects of feed intake and feed efficiency in dairy cattle: A review. Livest. Prod. Sci. 20:1-13.

Lidauer, M. H., J. Pösö, J. Pedersen, J. Lassen, P. Madsen, E. A. Mäntysaari, U. S. Nielsen, J.-A. Eriksson, K. Johansson, T. Pitkanen, I. Stranden, and G. P. Aamand. 2015. Across-country test-day model evaluations for Holstein, Nordic Red Cattle, and Jersey. J. Dairy Sci. 98:1296-1309.

Liinamo, A.-E., P. Mäntysaari, and E. A. Mäntysaari. 2012. Short communication: Genetic parameters for feed intake, production, and extent of negative energy balance in Nordic Red dairy cattle. J. Dairy Sci. 95:6788-6794.

Lund, M. S., G. Su, L. Janss, B. Guldbrandtsen, and R. F. Brøndum. 2014. Genomic evaluation of cattle in a multi-breed context. Livest. Sci. 166:101-110.

Mäntysaari, P., P. Huhtanen, J. Nousiainen, and M. Virkki. 2004. The effect of concentrate crude protein content and feeding strategy of total mixed ration on performance of primiparous dairy cows. Livest. Prod. Sci. 85:223-233.

Mäntysaari, P., P. Huhtanen, J. Nousiainen, and M. Virkki. 2005. The effect of protein-feeding strategy during lactation on performance of primiparous dairy cows fed total mixed ration. Livest. Prod. Sci. 94:189-198.

Mäntysaari, P., A.-E. Liinamo, and E. A. Mäntysaari. 2012. Energy efficiency and its relationship with milk, body, and intake traits and energy status among primiparous Nordic Red dairy cattle. J. Dairy Sci. 95:3200-3211.

Mäntysaari, P., and E. A. Mäntysaari. 2015. Modeling of daily body weights and body weight changes of Nordic Red cows. J. Dairy Sci. 98:6992-7002.

Mäntysaari, P., J. Nousiainen, and P. Huhtanen. 2003. The effect of constant or variable forage to concentrate ratio in total mixed ration on performance of primiparous dairy cows. Livest. Prod. Sci. $82: 27-37$

Manzanilla Pech, C. I. V., R. F. Veerkamp, M. P. L. Calus, J. E. Pryce, and Y. de Haas. 2014b. Genetic parameters and accuracy of recording dry matter intake in first parity Holstein-Friesian cows.
Proceedings of the 10th WCGALP Conference, Canada, Vancouver. Am. Soc. Anim. Sci., Champaign, IL.

Manzanilla Pech, C. I. V., R. F. Veerkamp, M. P. L. Calus, R. Zom, A. van Knegsel, J. E. Pryce, and Y. de Haas. 2014a. Genetic parameters across lactation for feed intake, fat- and protein-corrected milk, and liveweight in first-parity Holstein cattle. J. Dairy Sci. 97:5851-5862.

Manzanilla Pech, C. I. V., R. F. Veerkamp, R. J. Tempelman, M. L. van Pelt, K. A. Weigel, M. VandeHaar, T. J. Lawlor, D. M. Spurlock, L. E. Armentano, C. R. Staples, M. Hanigan, and Y. de Haas. 2016. Genetic parameters between feed-intake-related traits and conformation in 2 separate dairy populations - The Netherlands and United States. J. Dairy Sci. 99:443-457.

Mao, I. L., K. Sloniewski, P. Madsen, and J. Jensen. 2003. Changes in body condition score and in its genetic variation during lactation. Livest. Prod. Sci. 89:55-65.

Patel, M. 2012. Effects of increasing the proportion of high-quality grass silage in the diet of dairy cows. PhD. Thesis. Swedish University of Agricultural Sciences, Uppsala, Sweden.

Søndergaard, E., M. K. Sørensen, I. L. Mao, and J. Jensen. 2002 Genetic parameters of production, feed intake, body weight, body composition, and udder health in lactating dairy cows. Livest. Prod. Sci. 77:23-34.

Spurlock, D. M., J. C. M. Dekkers, R. Fernando, D. A. Koltes, and A. Wolc. 2012. Genetic parameters for energy balance, feed efficiency, and related traits in Holstein cattle. J. Dairy Sci. 95:5393-5402.

Tetens, J., G. Thaller, and N. Krattenmacher. 2014. Genetic and genomic dissection of dry matter intake at different lactation stages in primiparous Holstein cows. J. Dairy Sci. 97:520-531.

USDA. 2016. Monthly: National milk cost of production. USDA, Economic Research Service, Washington, DC. Accessed Jun. 16, 2016. http://www.ers.usda.gov/data-products/milk-cost-of-productionestimates.aspx.

Van Arendonk, J. A. M., G. J. Nieuwhof, H. Vos, and S. Korver. 1991. Genetic aspects of feed intake and efficiency in lactating dairy heifers. Livest. Prod. Sci. 29:263-275.

Veerkamp, R. F., and R. Thompson. 1999. A covariance function for feed intake, live weight, and milk yield estimated using a random regression model. J. Dairy Sci. 82:1565-1573. 